\title{
Performance and Emission Characteristics of Four Stroke Diesel Engine with Neem and Cotton Seed Biodiesel blended with Diesel
}

\author{
R. Ramachandra ${ }^{1}$, V. Pandurangadu ${ }^{2}$, K. Ashok Kumar Raju ${ }^{3}$ \\ ${ }^{1}$ Professor, Principal, S. K. D. Engineering College, Gooty, Ananthapuramu (D.T), A.P, India \\ ${ }^{2}$ Rector \& Professor of JNTUA, Ananthapuramu (D.T), A.P, India \\ ${ }^{3}$ Assistant Professor in Mechanical Engineering, SKDEC, Ananthapuramu, A.P, India
}

\begin{abstract}
The demand and price of petroleum based fuels are increasing at an alarming rate. If this situation continues there is every chance for the scarcity of petroleum products. A major solution to reduce this problem is to search for an alternative fuels. One of the best alternatives is Biodiesels obtained from different vegetable oils. The present study focuses on comparison of performance and emission characteristics of a single cylinder four stoke diesel engine with two different biodiesels namely Neem and Cotton seed biodiesels blended with diesel separately. The performance of the engine with biodiesel blend B20 as fuel is compared with the diesel fuel on the basis of brake specific fuel consumption, brake thermal efficiency, exhaust gas temperature and emissions of hydrocarbons and oxides of nitrogen. This study reveals that the performance of the engine with these biodiesel blends differ marginally from diesel and hydrocarbon emissions are less than diesel. It is also observed that the cotton seed biodiesel blends are showing better performance and emission characteristics as compared with neem biodiesel blends.
\end{abstract}

Keywords: Cotton seed biodiesel, Neem biodiesel, Performance and Emissions

\section{Introduction}

The depletion of world petroleum reserves and the global environmental pollution problems stimulated the search for the alternative source for petroleum based fuels. A major solution to reduce this problem is to search for an alternative fuels. Bio diesel [1] produced from vegetable oils can be used as an important alternative to the diesel oil, since they are renewable and can be produced in rural areas. The inventor of diesel engine Rudolf Diesel predicted that the plant based oils are widely used to operate diesel engine. The vegetable oil [2] has great potentials as alternative diesel fuel. Several researchers found [3] that the use of pure vegetable oils as fuel in diesel engine can cause numerous engine related problem such as injector choking, piston deposit formation and piston ring sticking due to higher viscosity and low volatility of vegetable oils. An effective method of using vegetable oils [4] in diesel engine is by modifying the vegetable oils into its monoesters (Biodiesel) by transestrification.

Transesterification [5] of vegetable oil provides a significant reduction in viscosity, thereby enhancing their physical and chemical properties and improve the engine performance. Though the biodiesel has several advantages [6] over pure vegetable oil, it has disadvantages like low calorific value, higher viscosity and poor cold flow properties as compared with diesel. This drawback may be managed with the employment of blended fuel of biodiesel and diesel fuel.

\section{Literature Review}

Researchers from various parts of the world have carried out various experiments on a diesel engine with various biodiesels and its blends with diesel to evaluate the performance and emission characteristics.

Dilip kumar et al (7) has conducted experiments on a CI engine with the biodiesel blends of cotton seed and neem biodiesels separately and suggested that the blend B20 is the optimum blend which can produce better performance for diesel engines.

Agarwal. A.K et al (8) has investigated the effect of the Karanja biodiesel blends on the DI diesel engine and concluded that the Karnja biodiesel can be used as a partial substitute of diesel up to 20\% (B20) without any major modifications in the existing engine.

Anbumani et al (9) and LoveKush Prasad et al (10) evaluated the performance of a single cylinder diesel engine with neem biodiesel blends and established that the neem biodiesel blend B20 can be used as fuel to run CI engine.

\section{Materials \& Methods}

In the present work engine tests were conducted with neem and Cotton seed Biodiesel blends separately to evaluate performance and emission characteristics. The performance of the engine with biodiesel blend B20 as fuel is compared with diesel fuel. Cotton [11] has long been known as nature's unique food and fiber plant. It produces both food for man and feed for animals in addition to a highly versatile fiber for clothing, home furnishings and industrial uses. Cottonseed oil [12] has a ratio of 2: 1 of poly un saturated to saturated fatty acids and generally consists of $65-70 \%$ unsaturated fatty acids including $18-24 \%$ monounsaturated (ole ic) and $42-52 \%$ polyunsaturated (linoleic) and 26-35\% saturated (palmitic and stearic). neem seed [13] is 


\section{International Journal of Science and Research (IJSR) \\ ISSN (Online): 2319-7064}

Index Copernicus Value (2013): 6.14 | Impact Factor (2015): 6.391

additionally known as Kochia Latifolia, It's also referred as Indian Butter Tree. Neem may be a medium to giant tree, which can attain a height of up to five meters. Its provender (oil cake) is employed as bio-fertilizer and organic manure.

It is a very important plant having vital socio-economic worth. This species will be planted on edges of roads and canal banks etc., on large scale and in social biological science programme, notably in social group (tribal) areas .

The various properties [14] of the above bio diesels are presented in table 1.

Table 1: Properties of fuels used

\begin{tabular}{|c|c|c|c|}
\hline Properties & $\begin{array}{c}\text { Cotton seed } \\
\text { biodiesel }\end{array}$ & $\begin{array}{c}\text { Neem } \\
\text { biodiesel }\end{array}$ & Diesel \\
\hline Density $(\mathrm{kg} / \mathrm{m} 3)$ & 874 & 919 & 830 \\
\hline Calorific Value $(\mathrm{kJ} / \mathrm{Kg})$ & 40600 & 35200 & 43000 \\
\hline Viscosity @40 ${ }^{0} \mathrm{C}(\mathrm{cSt})$ & 4.34 & 34 & 2.75 \\
\hline Cetan Number & 55 & 38 & 51 \\
\hline Flash Point $\left({ }^{\circ} \mathrm{C}\right)$ & 110 & 300 & 74 \\
\hline
\end{tabular}

\section{Technical specifications of the engine}

In this work experiments were conducted on 4 stroke, single cylinder, C.I engine (Kirloskar Oil Engineers Ltd., India) of maximum power-3.68 KW with AVL smoke meter and Delta $1600 \mathrm{~S}$ gas analyser.

\section{Results and discussions}

\section{A. Brake thermal Efficiency}

The Figure 1 shows the variation of brake thermal efficiency of the engine with break power output. It is observed that the brake thermal efficiency of the engine represents very similar trends for all the fuel samples. In general the thermal efficiency depends on the combustion process which is a complex phenomenon that is influenced by several factors such as design of combustion chamber, type of injection nozzle, injection pressure, spray characteristics and fuel characteristics such as cetane number, volatility, viscosity, homogeneous mixture formation, latent heat of vaporization, calorific value etc.

It is evident that diesel fuel has the higher brake thermal efficiency compared to biodiesel blends. It is also found that the cotton seed biodiesel blends has the highest thermal efficiency because of its calorific value and viscosity as compared with Neem biodiesel blends. With the higher calorific value the amount of heat produced in the combustion chamber is more, further the combustion is complete and produced higher temperatures. The efficiency of the engine with diesel is $27.82 \%$, neem biodiesel blend B20 is $25.72 \%$ and for the cotton seed biodiesel blend B20 it is $26.8 \%$ at $3 / 4^{\text {th }}$ of rated load. It is observed that the brake thermal potency of the engine with neem biodiesel blends is lower than the cotton seed biodiesel blends.

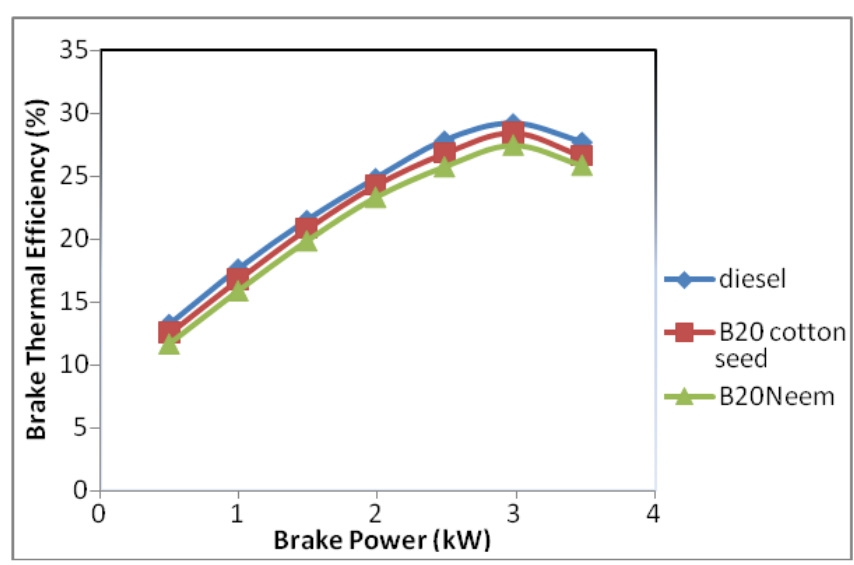

Figure 1: The variation of Brake thermal efficiency

\section{B. Brake specific Fuel Consumption}

The variation of brake specific fuel consumption (BSFC) with break power is shown in Figure 2.

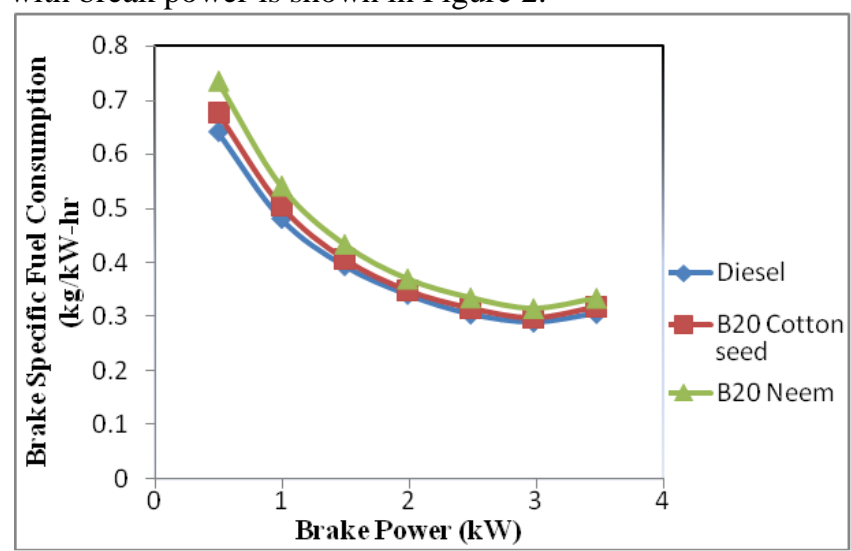

Figure 2: The variation of BSFC with brake power

The BSFC reduced with the load for all the fuels. The BSFC for all the biodiesel blends are higher than diesel fuel. The BSFC of cottonseed biodiesel blends are lower than the Neem biodiesel blends. The specific fuel consumption is increased by $14 \%$ and $9.31 \%$ respectively with Neem and cotton seed biodiesel blends compared with the diesel fuel. The BSFC is increased with increasing quantity of biodiesel in the blend because of the injection of less quantity of fuel due to the higher viscosity and lower heating value. The oxygenated biodiesels may lead to the leaner combustion resulting in higher BSFC. . It is also observed that the BSFC of the engine with Neem biodiesel blends is higher than the cottonseed biodiesel blends.

\section{Exhaust Gas Temperature}

The Figure 3 shows the variation of exhaust gas temperature of the engine with break power output. The exhaust gas temperature in the combustion chamber depends on the calorific value, latent heat and viscosity of the fuel injected. The exhaust gas temperature was found to extend with increase in both the concentration of biodiesel within the blend and engine load. The rise in EGT with engine load is due to the actual fact that a more quantity of fuel is needed within the engine to get additional power required to take up conditional loading. For the diesel the exhaust gas temperature is low as compared with the biodiesel blends. The exhaust gas temperature for the diesel is $285^{\circ} \mathrm{C}$, where as for Cotton seed biodiesel blend B20 and $296^{\circ} \mathrm{C}$, for Neem biodiesel blend B20 it is $302^{\circ} \mathrm{C}$ respectively at $3 / 4^{\text {th }}$ of rated 


\section{International Journal of Science and Research (IJSR) \\ ISSN (Online): 2319-7064 \\ Index Copernicus Value (2013): 6.14 | Impact Factor (2015): 6.391}

load. The exhaust gas temperature of Neem biodiesel blends is slightly higher than the cottonseed biodiesel blends.

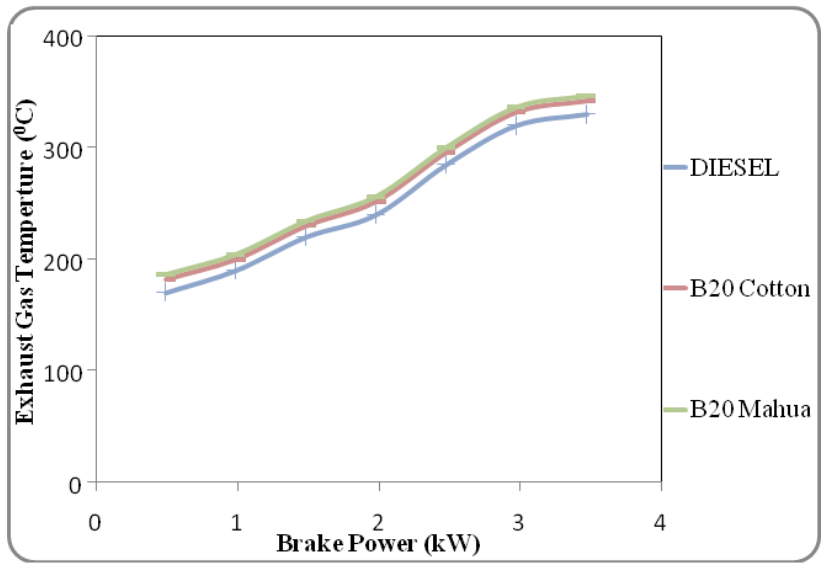

Figure 3: The variation of EGT with brake power

\section{Smoke Density}

The variation of the smoke densities with power output is shown in Figure 4.

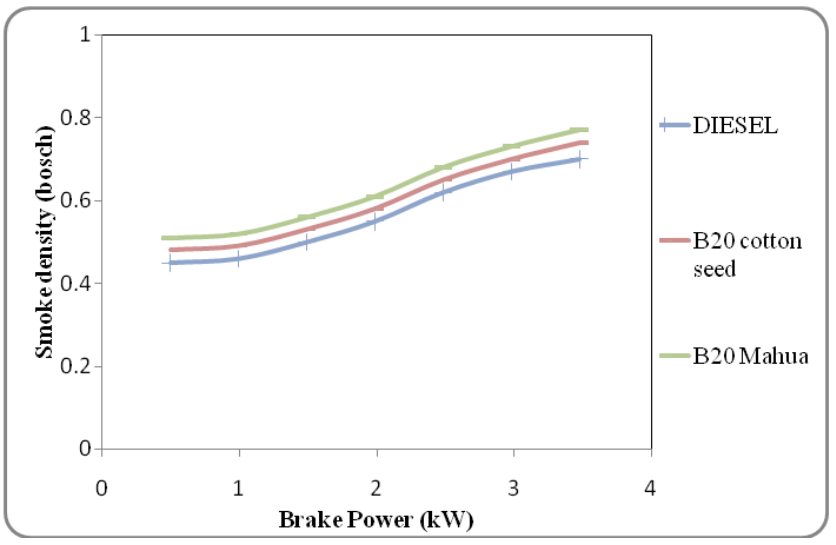

Figure 4: The variation of Smoke density with power output

The smoke capacity emissions increased with the increase of engine load. This is compensated up to certain extent due to the absence of aromatics and presence of inherent oxygen molecules in the biodiesel. These oxygen particles helps to promote stable and complete combustion by delivering oxygen to the combustion zone of burning fuel by reducing locally rich region and limit primary smoke formation and lower smoke emissions. Higher smoke emissions at higher loads may be due to poor atomization of biodiesel. When compared to diesel the increase in smoke emissions of biodiesel blends is higher due its high viscous nature. Due to higher viscosity of biodiesel the bigger size fuel molecules occurs and results in poor atomization of fuel.

\section{E. Hydrocarbon emissions (HC Emissions)}

The variation of hydrocarbon emissions with break power is shown in Figure 5. The HC emissions depend upon mixture strength i.e. oxygen quantity and fuel viscosity in turn atomization. The HC emissions increase with increasing load as well as increasing the amount of biodiesel in the blend. There will be similar trends for all the fuels. Lower heating value of biodiesel leads to the injection of higher quantities of fuel for the same load condition. More the amount biodiesel leads to more oxygen availability, either inherent in fuel or present in the charge. When compared to diesel, the oxygen availability in the biodiesels is more. So the HC emissions of the engine with biodiesel blends are less than diesel. The HC emissions of Neem biodiesel blends are slightly higher than the cotton seed biodiesel blends.

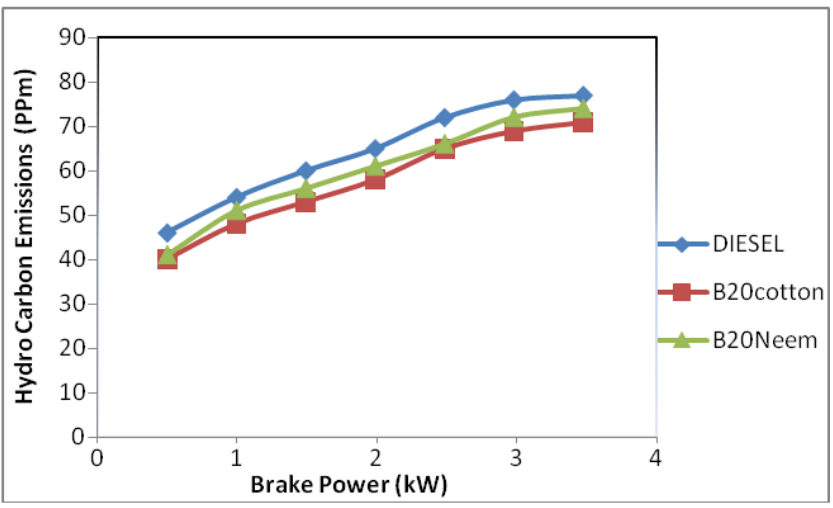

Figure 5: The variation of HC emissions with brake power

\section{F. Carbon Monoxide Emissions (co emissions)}

The variation of carbon monoxide emissions for is illustrated in Figure 6. It has been observed that the CO emissions are inflated with increase in engine load for all fuel samples. The $\mathrm{CO}$ emission of the engine with diesel oil is higher than the Cotton seed and Neem biodiesel blends. The lower CO emission of biodiesel compared to diesel oil is due to the presence of oxygen in biodiesel that helps in complete oxidization of fuel. The surplus oxygen offered within the biodiesel converts the some of the $\mathrm{CO}$ into carbon dioxide and thus the CO emission is reduced. The CO emission for diesel oil is $0.63 \%$ volume, for Cotton seed biodiesel blend B20 is $0.6 \%$ volume and for Neem biodiesel blend B20 is $0.59 \%$ volume at $3 / 4$ th of rated load. The CO emissions of Neem biodiesel blends are slightly higher than the cottonseed biodiesel blends.

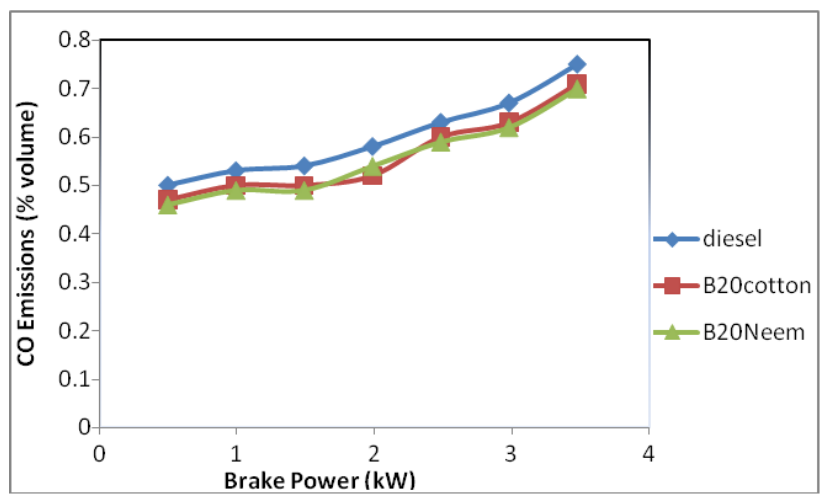

Figure 6: The variation of $\mathrm{CO}$ emissions with brake power

\section{G. Nitrogen oxide Emissions}

The variation of Nitrogen oxide emissions of the engine with diesel and biodiesels are illustrated in Figure 7. The NOx emission will increase with increase in load on the engine for each diesel and biodiesel blends. These higher NOx emissions could be due to the higher exhaust gas temperature at higher loads. The NOx emissions are slightly higher for Cottonseed biodiesel blends as compared with pure diesel. The rise of NOx emissions could also be related to the oxygen content of the biodiesel, since the biodiesel fuel provided extra oxygen for NOx formation. This one 


\section{International Journal of Science and Research (IJSR) \\ ISSN (Online): 2319-7064 \\ Index Copernicus Value (2013): 6.14 | Impact Factor (2015): 6.391}

amongst the most reasons for the formation of higher NOx with the biodiesel blends as compared with pure diesel. The NOx emissions of Neem biodiesel blends are slightly higher than the cotton seed biodiesel blends.

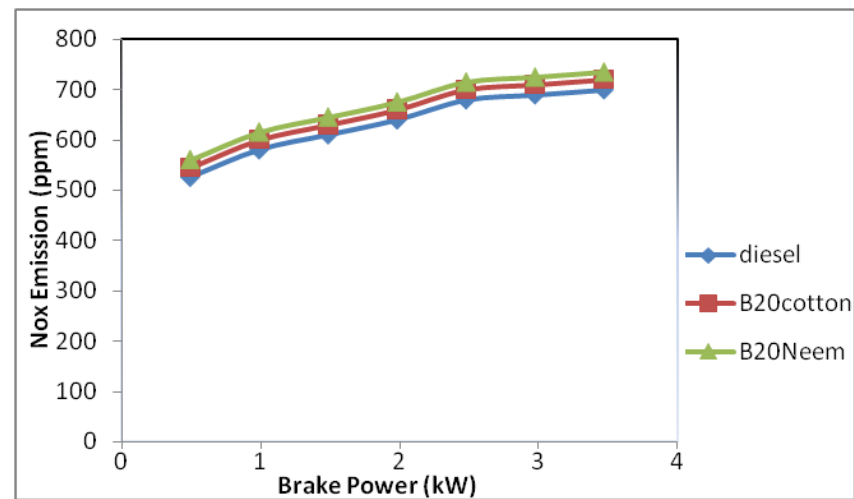

Figure 7: The variation of Nitrogen oxide emissions

\section{Conclusions}

The following conclusions are drawn based on the experimental results of the above work:

- The brake thermal efficiency of the engine depends majorly on the heating value and viscosity. The brake thermal efficiency of biodiesel blends is lower than the diesel. The cotton seed biodiesel blends is having brake thermal efficiency higher than the Neem biodiesel blends.

- The BSFC of the engine with diesel fuel is lower than the biodiesel blends and the BSFC of cotton seed biodiesel blends is lower than the Neem biodiesel blends.

- The exhaust gas temperature of the engine with diesel fuel is higher than the biodiesel blends.

- The CO and HC emissions of the engine with diesel fuel is lower than the biodiesel blends and the $\mathrm{CO}$ and $\mathrm{HC}$ emissions of cotton seed biodiesel blends is lower than the Neem biodiesel blends.

- The Smoke and NOx emissions of the engine with diesel fuel are higher than the biodiesel blends.

It is concluded that out of the two biodiesels cotton seed biodiesel is best as compared with Neem biodiesel in terms of performance and emissions. So the cotton seed oil can be used as alternative to diesel.

\section{References}

[1] Cummins, C., Lyle, Jr. (1993). Diesel's Engine, Volume 1: From Conception to 1918.Wilsonville, OR, USA: Carnot Press, ISBN 978-0-917308-03-1.

[2] Agarwal A.K and Das L.M, Bio diesel development and characterization for use as a fuel in CI engine, Transaction of ASME 2001-123, 440- 447

[3] Senthil Kumar, M.; Ramesh, A.; Nalagingam, B., "Proceedings of the International Conference on WASTE to ENERGY," Jaipur, India, 2002, 85-92.

[4] Bari, S., Lim, T.H., Yu, C.W. (2002). Effect of preheating of crude palm oil on injection system

[5] Scholl Wk, Sorenson CS "Combustion of soyabean oil methyl ester in DI diesel engine". SAE 1983 930-934.

[6] Sahoo PK, Das LM, Babu MKG and Naik SN, "Biodiesel development from high acid value polanga seed oil and performance evaluation in CI engine". 2007;86(3): 448-454.

[7] Dilip kumar, and Ravindra kumar, Experimental investigation of cotton seed oil and neem methyl esters as biodiesel on $\mathrm{CI}$ engine, International journal of modern engineering research (IJMER), Vol. 2, Issue. 4,July- Aug-2012. PP. 1741-1746.

[8] Avinash Kumar agarwal and Atul Dhar, Experimental investigations on the effect of Karanja biodiesel on engine performance, combustion and durability, in collabration with Shell technology India PVT, Directions -2013, PP. 93-100.

[9] Anbumani and Ajith pal sing, Performance of Mustard and Neem oil blends with diesel in CI engine, ARPN Journal of engineering and applied science, Vol. 5, Issue. 4, April-2010, PP. 14-20.

[10]Love Kush prasad and Alka Agrawal, Experimental investigations of diesel engine working on diesel and neem oil blends, IOSR Journal of mechanical and civil engineering (IOSRJMCE), Vol. 1, Issue. 4, July-AUG2012, pp. 48-51.

[11] Adelola and Andrew, International Journal of Basic \& Applied Science Vol 1, 02 Oct 2012.

[12]Dinesh and Singh, Cotton Seed oil quality utilization and processing - CICR Technical bulletin No. 25.

[13] Bhat, Y C.; Murthy, N.S.; and Datta, R.K., 2004, Journal of Institute of Engineers (India) - AG, 85, 10 14.

[14] Report of the committee on Development of Bio fuelsPlanning Commission, Government of India. 